\title{
UKRAIŃSKIE NARRACJE TOŻSAMOŚCIOWE. PRZYKŁAD IWANA FRANKI I ŁESI UKRAINKI
}

\author{
Marta Kaczmarczyk \\ Katolicki Uniwersytet Lubelski Jana Pawła II, Lublin, Polska \\ ORCID 0000-0002-8840-5509
}

\begin{abstract}
Streszczenie: Autor artykułu analizuje wybrane przykłady działalności Iwana Franki oraz Łesi Ukrainki, zwracając uwagę na te jej przejawy, których centrum jest kwestia tożsamości ukraińskiej, potrzeba jej budowania i umacniania, bo tylko dzięki temu Ukraińcy i Ukraina są w stanie proklamować swoją odrębność. Pisarze, reprezentujący rozdzielone politycznymi granicami części Ukrainy, realizują w swojej działalności narracje antykolonialne.
\end{abstract}

Słowa kluczowe: Iwan Franko, Łesia Ukrainka, tożsamość ukraińska, tożsamość narodowa, literatura ukraińska, pisarze ukraińscy.

Kwestia tożsamości, manifestacja przynależności do narodu ukraińskiego borykającego się zarówno w przeszłości, jak i współcześnie z szeregiem problemów o charakterze narodowowyzwoleńczym, była i, jak się okazuje, jest po dzień dzisiejszy sprawą priorytetową dla Ukrainy. Proces kształtowania tożsamości ukraińskiej, podobnie zresztą jak sam proces kształtowania się Ukrainy jako państwa oraz Ukraińców jako narodu, przebiegał dość powoli oraz był przerywany czy spowalniany przez różnego rodzaju okoliczności historyczne i polityczne. Ziemie ukraińskie, często określane mianem pogranicza ${ }^{1}$, przez stulecia znajdowały się w zmieniającej się strefie wpływów. Historia Ukrainy to, jak zauważył Wołodymyr Wynnyczenko, szereg wojen, bitew, powstań, intryg, z którymi borykał się naród, potrafiąc jedynie odszczekiwać się swoim najeźdźcom, wśród których byli nie tylko Rosjanie, ale również Polacy, Tatarzy czy Szwedzi². W obliczu braku państwowości i konsolidacji narodowej, w warunkach obcej dominacji politycznej, ekonomicznej i kulturalnej, Ukra-

$1 \quad$ Zob. A. Reid, Pogranicze. Podróż przez historię Ukrainy 988-2015, przeł. W. Tyszka, Warszawa 2016.

2 В. Винниченко, Щоденник [фрагменти], передм. М. Жулинський, Київ 1990, № 9, s. 122 . 
ińcy poddawani byli, zwłaszcza ze strony Imperium Rosyjskiego, różnego rodzaju strategiom kolonizacyjnym zmierzającym do stopniowego wchłonięcia ich przez kolonizatora, rzekomo dla ich własnego dobra ${ }^{3}$. Proces wchłaniania może przebiegać dość swobodnie wobec braku poczucia własnej inności ${ }^{4}$, rozeznania odrębności swojej kultury, braku mentalnej wolności względem tożsamości kolonizatora. Zjawisko to zostało zauważone i opisane zwłaszcza w odniesieniu do tak zwanego „białego kolonializmu”, kiedy to podbite ziemie nie leżą, rzec można, daleko za morzami czy oceanami, ale usytuowane są po sąsiedzku z rdzennym terytorium kolonizatora, a podbita ludność nie różni się od populacji państwa imperialnego rasowo i jest do niej bardzo zbliżona pod względem antropologicznym.

Typowym przykładem takiego imperium była carska Rosja, a po zniesieniu rządów carskich w wyniku rewolucji - ZSRR. Ukraina w swej tragicznej historii była $i$, niestety, pod wieloma względami dalej jest typowym przykładem kolonii Rosji, która przez okres ponad 300-letniej dominacji nie tylko eksploatowała jej ziemie, bogactwa kulturowe i materialne, ale przywłaszczyła sobie ukraińską historię, a nawet nazwę; utożsamiła się z nią. Już w okresie caratu głoszone były hasła: „єдиная вєра, єдиной язык - єдиной народ", które hamowały rozwój ukraińskiej kultury. Władze carskie, potem komunistyczne, zabraniały używania języka ukraińskiego, a tam, gdzie nie dało się zakazu egzekwować, a więc w odniesieniu do licznej i żywotnej ludności ukraińskich wsi, sprowadzano ją do poziomu gorszych mieszkańców państwa, śmiesznych i prymitywnych miejscowych „ruskich”, do rzędu osobliwości określanych pogardliwie brzmiącym słowem „,chachły”. Czarną skórą Ukraińców był - jak to określił Mykoła Riabczuk - ich „czarny” ukraiński język (ubogi, pogardzany, upośledzony „kołchozowy język”), z którym można było w przeważającej większości rozprawić się poprzez rusyfikację już w drugim pokoleniu. Głównym celem i zadaniem rosyjskich strategii imperialnych była między innymi transformacja pamięci Ukraińców, unicestwianie ich poczucia godności narodowej, szacunku do siebie, ciągłe podsycanie kompleksu niższości.

W tym kontekście adekwatne okazuje się przywołanie opinii znanego amerykańskiego badacza, Frantza Fanona, który słusznie zauważył, że „najeźdźcy nie wystarcza obiektywny fakt niszczenia narodu i jego kultury. Do-

Zob. cytat z przemówienia A. J. Balfoura, [w:] E. W. Said, Orientalizm, przeł. M. Wyrwas-Wiśniewska, Poznań 2005, s. 69.

4 Inność jest - jak zauważył Dariusz Skórczewski - rewersem tożsamości; jest jej nieodłączną częścią. Zob. D. Skórczewski, Teoria - Literatura-Dyskurs. Pejzaż postkolonialny, Lublin 2013, s. 7.

$5 \quad$ M. Riabczuk, Kolonializm inaczej. O przydatności metodologii postkolonialnej do badań nad Europa postkomunistyczna, przeł. K. Kotyńska, [w:] Idem, Ukraina. Syndrom postkolonialny, Wrocław - Wojnowice 2005, s. 32. 
maga się, żeby mieszkaniec kolonii uznał niższość swojej kultury", czemu odpowiada przyznanie wyższości kulturze najeźdźcy. Jak się wydaje, to ostatnie stwierdzenie jest kluczowe przy wskazywaniu mechanizmów działania w przypadku ,,białych kolonializmów”, a przynajmniej tego w wydaniu rosyjskim, gdzie mamy do czynienia z podporządkowywaniem sobie ,białych aborygenów", takich jak Ukraińcy.

Pomimo wiekowej i skutecznej w wielu wypadkach praktyki Rosji, która wchłonęła wiele narodów i ich kultur, nie udało się temu imperium definitywnie $\mathrm{i}$ bez reszty pochłonąć Ukrainy. Ukraińska tożsamość oraz świadomość terytorialna nie przepadła bez reszty, pomimo wieloletniego podziału ukraińskich ziem pomiędzy różne organizmy państwowe, które stosowały, co warto podkreślić, własne strategie unifikacji. Nad fenomenem tym można by się długo zastanawiać, wydaje się wszakże, że w głębi świadomości zagrożonych narodów, szczególnie tych wielkich liczebnie, istnieje jakaś naturalna, żywotna, instynktowna dążność do przetrwania (wszystko, co pojawia się w sposób naturalny, przejawia wolę dalszego istnienia) ${ }^{7}$. Na tym instynkcie opiera się aktywność warstwy inteligenckiej zagrożonej populacji, wykorzystując go w programach i projektach narodowotwórczych i obronnych.

W narodzie ukraińskim, podobnie jak w innych europejskich narodach bezpaństwowych, w XIX wieku została rozbudzona samoświadomość właśnie dzięki takim programom, które powstawały przede wszystkim w środowisku inteligencji i humanistów - pisarzy, historyków, etnografów, folklorystów - którzy w swoich tekstach zwracali uwagę na ukraińską odmienność, odrębność historii, kultury, języka czy obrazu świata i przypominali o istnieniu różnic pomiędzy tożsamością ukraińską a imperialnym dyskursem kolonialnym. Właśnie dzięki takiemu stanowisku twórców, wyrażanemu między innymi poprzez literackie narracje, dzięki podkreślaniu unikalności i odrębności poszczególnych narodów, dały wówczas znać o sobie przebudzone narody europejskie nie posiadające własnych państw, tak zwane narody filologiczne.

„Państwa słowa” istniały początkowo, jak powiedzielibyśmy to dzisiaj, tylko wirtualnie, w przestrzeni kultury, głównie literatury, aby stopniowo formować tożsamość narodową we wszystkich warstwach społecznych oraz

\footnotetext{
6 F. Fannon, Wyklęty lud ziemi, przeł. H. Tygielska, z posłowiem Jean-Paula Sartre'a, Warszawa 1985, s. 26.

7 Nad tym fenomenem zastanawia się również wybitny ukraiński badacz Jarosław Hrycak, stawiając pytanie, jak Ukraińcom w tak niesprzyjających okolicznościach udało się przekształcić w nowoczesny naród. W ogóle zastanawiające jest, jak Ukraińcom udało się sformować naród. Bo jeśli przyjąć klasyczne definicje, zgodnie z którymi naród wyróżnia posiadanie wspólnego dla wszystkich kodu porozumiewania się, czyli języka, wspólnej pamięci historycznej oraz wyznania, to Ukraińcy tak do końca nie spełniają żadnego z tych trzech kryteriów. Zob. Я. Грицак, Нариси історії Украӥни: формування модерної української наиії XIX-XX cm., Київ 1996, s. 5 i n.
} 
przygotowywać je do urzeczywistnienia idei utworzenia organizmu politycznego na zamieszkiwanym przez naród terytorium. Stąd pisarze ukraińscy przyjęli na siebie szczególne zadanie tworzenia literatury narodowej i takiego oddziaływania na odbiorców, by poprzez swoje utwory kształtować w nich ukraińską tożsamość. Był to z pewnością cel pozaartystyczny, twórcy zdawali sobie jednak sprawę, że w istniejącej sytuacji w pierwszej kolejności muszą być przewodnikami narodu, nauczycielami patriotycznych postaw, a dopiero potem pisarzami.

Należy zaznaczyć, że takich obowiązków nie mieli pisarze tych narodowości, które nie podlegały procesom kolonizacyjnym. Zrozumiały jest fakt, że $\mathrm{w}$ tak trudnych dla Ukraińców warunkach ${ }^{8}$ kolonizacyjnej polityki prowadzonej przez Imperium Rosyjskie, decyzja o pozostaniu pisarzem ukraińskim niosła z sobą duże ryzyko i wiązała się często z prześladowaniami, aresztowaniami, utratą pracy, poniewierką, a nawet wczesną śmiercią (jako przykład mogą posłużyć losy Tarasa Szewczenki, Stepana Rudnyckiego, Anatola Swydnyckiego i innych) ${ }^{9}$. Należy tu wspomnieć jeszcze jedną cechę szczególną ukraińskiej literatury kolonialnej, a mianowicie fakt, że „zawód” pisarza tego okresu był, po pierwsze, mało dochodowy, co było wynikiem niemożliwości publikacji w warunkach funkcjonowania cenzury oraz zakazów tworzenia w języku ukraińskim ${ }^{10}$, po drugie zaś było to zajęcie społecznie mało prestiżowe.

Rosja, opanowawszy Ukrainę, od samego początku starała się zneutralizować wszystkie możliwe ogniska sprzeciwu wobec ekspansji, oferując różne

$8 \quad$ Zakaz używania języka ukraińskiego, a co za tym idzie blokowanie literatury ukraińskiej (zakaz publikowania w języku ukraińskim, wystawiania spektakli w języku ukraińskim itp.) stanowią działanie bezprecedensowe, antyukraińskie, trwające faktycznie w ciągu całego okresu dominacji Rosji nad Ukrainą, począwszy od XVIII wieku.

9 Warto tu przytoczyć przykład Panasa Rudczenki, który, bynajmniej nie dla własnego kaprysu, będąc dość wysoko postawionym urzędnikiem administracji carskiej, nie przyznawał się, że to on jest tym Panasem Myrnym, którego poszukiwała cała carska policja. Nie zdradzał swojego sekretu nawet redaktorom czasopism galicyjskich (zagranicznych, bo znajdujących się na ziemiach Austro-Węgier).

10 Wystarczy wspomnieć o trudnej sytuacji materialnej Łesi Ukrainki, która była przecież wybitną, znaną i szanowaną przedstawicielką literatury ukraińskiej, mimo to nie ominęły jej problemy finansowe. Kiedy część spadku, którą odziedziczyła po rodzicach, znacznie się uszczupliła, pisarka została zmuszona do aktywności mogącej zapewnić jej utrzymanie. Między innymi w celach zarobkowych pisała artykuły w języku rosyjskim, który, rzekomo, znała gorzej niż francuski (sic!). Teksty w języku ukraińskim nie mogły się bowiem legalnie ukazać w imperium. Jeśli zatem pisarka tej miary borykała się z problemami materialnymi, to można sobie wyobrazić, jaka była sytuacja twórców, którzy nie mogli pochwalić się tak świetnym piórem jak Ukrainka. Tytułem uzupełnienia warto dodać, że potrzeby, a co za tym idzie, wydatki Ukrainki były szczególnego rodzaju: częste podróże, zagraniczne leczenie, operacje, rekonwalescencje itp., a wszystko to generowało koszty, których pokrycie szybko uszczupliło posiadany majątek, zmuszając poetkę do podejmowania prac zarobkowych. 
korzyści członkom wyższych warstw ukraińskiego społeczeństwa, w zamian oczekując ich lojalności. W niedługim czasie „opłacani” przedstawiciele tych grup społecznych denacjonalizowali się - stawali się rosyjskimi dworzanami. W strefie polskich wpływów natomiast wyższe warstwy społeczne polonizowały się. Z tego też względu twórcami ukraińskiej literatury, kultury, wreszcie budzicielami narodowej świadomości oraz kreatorami ukraińskiej tożsamości byli przedstawiciele średniej warstwy społecznej, a czasem nawet, jak w przypadku Szewczenki, twórcy wywodzący się z najniższej, najbardziej społecznie (i narodowo) upośledzonej warstwy ukraińskiej społeczności - chłopów pańszczyźnianych, czyli de facto białych niewolników. Ukraińcy wyższych warstw, jeśli odkrywali w sobie talent pisarski, decydowali się raczej zostać twórcami rosyjskimi, jak uczynił to chociażby Mikołaj Gogol.

Mogło to oznaczać i często oznaczało potencjalne obniżenie poziomu artystycznego oraz zawężenie horyzontów intelektualnych dyskursu kulturowego - pamiętać należy, że decydowali się na tę opcję przeważnie ludzie niezamożni, pozbawieni możliwości uzyskania solidnego, systematycznego wykształcenia. Perspektywa bycia pisarzem stanowiła dla nich nierzadko jedyną możliwość rozwoju, wyrażenia samego siebie. Status pisarza był swego rodzaju windą społeczną, bo, choć to paradoksalne, zapewniał pewien prestiż (czy sławę, jeśli wyrazić to w duchu nomenklatury XIX wieku), wyższą pozycję w swego rodzaju „kolonialnym getcie”, ponieważ kultura ukraińska, podobnie jak kultura innych skolonizowanych narodów, nie mogła być partnerką międzykulturowego dyskursu, gdyż była pozbawiona prawa głosu. Należy także wziąć pod uwagę fakt, że wynaradawianie się najbardziej wykształconych i twórczych jednostek powodowało pewne wyjałowienie w kręgach ukraińskich, co skutkowało brakiem konkurencji, a czasem otwierało drzwi do literatury niezbyt utalentowanym autorom, którzy w normalnych warunkach nie mieliby żadnych szans, żeby zostać pisarzami.

Niezależnie od tego niezaprzeczalną i niepodważalną sławę tak wśród współczesnych, jak i potomnych, mogli zdobyć (i zdobywali) tylko prawdziwie utalentowani pisarze oraz twórcy oddani narodowi i posłannictwu kształtowania narodowej tożsamości. Do takich z całą pewnością należą Iwan Franko i Łesia Ukrainka. Warto się zatem przyjrzeć, jak owi twórcy, najwyższe autorytety w zakresie tworzenia literatury ukraińskiej, kreowali swoje ukraińskie narracje tożsamościowe.

Iwan Franko urodził się w 1856 w Galicji Wschodniej, będącej wówczas częścią Cesarstwa Austro-Węgierskiego. Pomimo dość łagodnego panowania Habsburgów, co niewątpliwie przyczyniło się do powstania i rozkwitu w Galicji ukraińskiego ruchu narodowego, była to ziemia naznaczona nierównością społeczną i sprzecznością narodowościowych interesów zamieszkujących ją Polaków, Ukraińców, Żydów i niewielkiej garstki Austriaków, nie wspominając o mniej licznie reprezentowanych narodowościach. Stanowiąca zdecy- 
dowaną większość ludność ukraińska reprezentowała głównie najniższą warstwę społeczną - chłopów, którzy borykali się z różnego rodzaju uciskiem czy to ze strony polskich panów, czy Żydów. Kwestia przynależności narodowej oraz świadomość własnej tożsamości wśród tej warstwy społecznej była nikła. Włościanie, jak ich wówczas nazywano, postrzegali siebie jako chłopów, nazywali siebie „tutejszymi” i dopiero pod koniec XIX wieku zaczęli myśleć o sobie jako o Ukraińcach ${ }^{11}$. Wobec takiego stanu świadomości społecznej pisarze, bo głównie o nich będzie tu mowa, podjęli się zadania kształtowania narodowej tożsamości wśród ludności ukraińskiej. Takiego zadania podjął się między innymi Franko. Jako przedstawiciel środowiska chłopskiego, będąc jeszcze młodym człowiekiem, wybrał indywidualną - ukraińską (według ówczesnego nazewnictwa: ruską) - tożsamość i los pisarza ukraińskiego. Iwan Franko na stałe wszedł do kanonu literatury ukraińskiej i aż do śmierci w 1916 roku był kreatorem i inspiratorem wszystkich wydarzeń życia społeczno-kulturalnego zarówno w Galicji, jak i na całej Ukrainie.

$\mathrm{Na}$ powstanie fenomenu, jakim okazał się Franko, wpływ miało wiele czynników. Najpierw wskazać należy przyczyny subiektywne, indywidualne: wrodzony talent twórcy, jego nieprzeciętną osobowość, pracowitość i charyzmę, także pochodzenie, które zmuszało go do nieustannej walki o własne miejsce w społeczeństwie, w końcu okoliczności związane z życiem osobistym, w tym utratę ojca w wieku 9 lat, co bez wątpienia nauczyło przyszłego pisarza liczyć tylko na siebie i na własne siły. Do czynników obiektywnych, zewnętrznych zaliczyć należy tzw. ,społeczne zapotrzebowanie na Frankę”, palącą potrzebę posiadania przez zagrożoną w swym bycie wspólnotę etniczną człowieka, który byłby jej reprezentantem i obrońcą, ale także wizjonerem przyszłości, twórcą programu przebudowy etnicznej masy w świadomy siebie naród. Czynniki te motywowały Frankę do, jak sam mówił, „служіння двом провідним зорям - своєму рідному народові і загальнолюдським поступовим ідеям”, tym, jak sam pisze, „двом провідним зорям” Franko „не споневірявся ніколи...”" .

Światopogląd Franki, człowieka spragnionego wiedzy, otwartego na nowe idee, przeszedł pewną ewolucję. Był on prawdziwym semper tiro. Uczył się po to, by dzielić się wiedzą, żeby „пересадити на руський грунт, мов чужоземну, але сильну рослину [...] всі нові думки, нові ідеї, винаходки людського розуму, все, що прояснює людський світогляд, все, що йде до світла, вольности, щастя" "13. Czyli wszystko, co mogło podnieść Ukraińców do poziomu bardziej kulturowo rozwiniętych narodów, sformować, ukształtować ze wspólnoty etnicznej naród europejski.

Zob. A. Reid, op. cit., s. 121.

I. Франко, Зібрання творів: У 50-ти томах, t. 3, Київ 1976, s. 282.

Idem, Зібрання творів: У 50-ти томах, t. 45, Київ 1986, s. 141-142. 
W czasach Franki, czyli od II połowy XIX wieku, ścierały się w Europie dwa światopoglądy - socjalizm i nacjonalizm. W młodości Franko był liberalnym socjalistą, jednym z organizatorów radykalnej (socjalistycznej) partii w Galicji, ale nigdy nie był kosmopolitą. W jego wizjach szczęśliwej przyszłości, opartej na ideałach socjalistycznych, „ludzkim braterstwie” i pracy na „wspólnej ziemi” („спільній ріллі”), zawsze była obecna Ukraina, „ојczyzna” („край рідний”), „zapomniana przez wszystkich i ograbiona przez obcych” („обдертий чужими і світом забутий”), teraz już „wolna, nowa” („свобідна, нова”). Jarosław Hrycak nazywa taką, naówczas nietypową postawę, „формулою Франка"14.

Poczynając od połowy lat 80., Franko stopniowo przechodzi na stanowisko ukraińskiego demokraty, czy dokładniej - kulturowego nacjonalisty. Chociaż socjalistyczne idee sprawiedliwości społecznej i równości nadal są dla niego ważne, to występuje on z ostrą krytyką socjalizmu jako modelu organizacji społecznej (w szczególności w zakazanej w czasach radzieckich pracy Що таке постуn?, a także w obszernym artykule Суспільно-політичні погляди Михайла Драгоманова): „Розвій народності без розвою живого народу, його добробуту, освіти і рівності громадської і прав горожанських є або пустою мрією, доктриною, або штучним тепличним витвором"15. W 1895 roku Franko zakłada ukraińską partię narodowo-demokratyczną, a w swoich pracach filozoficznych, publicystycznych, pedagogicznych czy etnologicznych podaje podstawowe założenia programu kształtowania narodu ukraińskiego i świadomości narodowej, w dalszej perspektywie zdobycia przez Ukrainę państwowej niezależności.

Iwan Franko nieustannie zastanawia się nad kwestią osobliwości ukraińskiej tożsamości kulturowej, nad prawem Ukraińców do samostanowienia o sobie i prawem do własnego państwa, porusza te kwestie już w pismach okresu „socjalistycznego". We wczesnej pracy Наш погляд на польське питання (1883) autor polemizuje z ówczesną polską doktryną imperialną „od morza do morza", przeciwstawiając jej ukraiński pogląd na tę kwestię. Pisze, że perspektywa budowy państwa polskiego w granicach „historycznej Polski” oznaczałaby dla Ukraińców kolonizację, zatem niesprawiedliwość, bo każdy naród ma prawo do własnego państwa na swojej ziemi. Takie samo prawo mają zarówno Polacy, jak i Ukraińcy: „Почуваючи незнищиму і історією в нас виховану ненависть до всякого гніту і насилля, ми бажаємо повної, і національної, і політичної, свободи полякам. Але тільки під тим необхідним условієм, що вони раз назавжди зречуться опіки над нами, раз назавжди покинуть будувати історичну Польщу на непольських землях,

14 Я. Грицак, Пророк у своїй вітчизні. Франко та його спільнота (1856-1886), Київ 2006.

15 I. Франко, Зібрання творів: У 50-ти томах, t. 27, Київ 1980, s. 335. 
а стануть так само, як і ми, на становищі Польщі чисто етнографічноі”"16. W swoich rozważaniach nad tym tematem Franko wychodzi od idei „równoprawności i autonomii każdego odrębnego narodu” - „єдиного надійного фундаменту в міжнародних стосунках”. Uważa, że „найперша задача кожного народу є стояти за власними інтересами і дбати про своє власне утримання" 17.

W artykule Ukraina irredenta $(1895)^{18}$, który nie wszedł do 50-tomowego wydania utworów Franki, ponieważ został przez radzieckich wydawców uznany za nacjonalistyczny (w ZSRR ukazywano Frankę jako socjalistę, i to prawie bolszewickiego pokroju), autor daje dość obszerny rys historyczny ukazujący formowanie się ukraińskiej idei narodowej poczynając od XVI wieku, i dowodzi potrzeby politycznego samookreślenia się Ukrainy. Dalszy rozwój idei narodotwórczych poety można odnaleźć w pracach z początku XX wieku: Поза межами можливого (1900), Одвертий лист до галицької української молодежі (1905), «Ідеї» й «ідеали» галицької москвофільської молодежі (1905), Суспільно-політичні погляди Михайла Драгоманова (1906), które badacz Iwan Denysiuk określił mianem „маніфесту націєтворення" 19 .

Największe nadzieje pokładał Franko w młodzieży ukraińskiej i właśnie do niej kierował swoje narodowotwórcze porady i refleksje. Jeszcze na początku XX wieku, przewidując zmiany polityczne na mapie Europy, słusznie uważał, że naród ukraiński powinien być gotowy na przyjęcie wyzwania czasu i skorzystania ze zmian w celu stworzenia własnej państwowości, które to zadanie mają zrealizować młodzi ludzie. W artykule programowym Одвертий лист до галицької украӥнської молодежі (1905) Franko pisze, że dla zachowania ukraińskiej tożsamości narodowej najważniejsze jest umocnienie idei niezależności państwowej. Właśnie taki ideał, jak uważał Franko, pomoże najlepszym siłom ukraińskim prowadzić zwycięską walkę o wyzwolenie narodowe i „критично сприймати ідеї марксівського економічного матеріалізму чи фаталізму”. Dlatego „мусимо вживати всіх сил і засобів, щоб наближуватись до нього"20. W tym kontekście pisarz niejednokrotnie wypowiadał się o imperialnej Rosji i zagrożeniu, jakie stanowi ona dla przyszłego państwa ukraińskiego. Przewidywał, że mocarstwo to znów

\footnotetext{
16 Idem, Наш погляд на польське питання, [w:] Idem, Зібрання творів: У 50-ти томах, t. 45 , s. 218.

17 Ibidem, s. 208.

18 I. Франко, Ukraina irredenta, [w:] Idem, Мозайка: Із творів, щяо не увійшли до Зібрання творів у 50 томах, упоряд. З. Франко, М. Василенко, Львів 2001.

19 І. Денисюк, Літературознавчі та фольлористичні праці у 3 томах, t. 2: Франкознавчі дослідження, Львів 2005.

20 I. Франко, Одвертий лист до галицької украӥнської молодежі, [w:] Idem, Зібрання творів: У 50-ти томах, t. 45, s. 285.
} 
będzie prowadzić politykę wyzyskiwania, niszczenia i ogłupiania „obrzeży” dla „dobra centrum"

Szczególne miejsce w programie rozwoju kulturalno-narodowego Ukrainy przypisuje Franko jednej z podstaw tożsamości narodowej, jaką jest język ojczysty, „tajemnicza siła [...], której porzucić bez konsekwencji dla stanu duszy nie można, podobnie, jak nie można zrzucić z siebie skóry". Odwołuje się tu pisarz do postawy Gogola i jego decyzji o tworzeniu w języku rosyjskim, co zostało określone mianem rozdwojenia duszy22. Dalej Franko podkreśla, że tylko ludzie emocjonalnie, nawet mistycznie przywiązani do ziemi ojczystej, kultury, języka, sumiennie pracujący na jego rzecz, są w stanie podźwignąć naród ukraiński i stanąć na jego czele, kiedy przyjdzie odpowiedni $\operatorname{czas}^{23}$.

Zarówno poprzez swoje życie, jak i twórczość, Franko był właśnie takim człowiekiem - wzorem i przykładem do naśladowania dla jemu współczesnych oraz dla młodszych pokoleń. W swojej twórczości nie tylko sformułował program narodowo-kulturowego rozwoju Ukrainy, ale też starał się przygotować i wychować świadomych narodowo, wykształconych ludzi, będących w stanie wcielić te idee w życie, przekształcić ideę narodu ukraińskiego w rzeczywistą narodową samodzielność i niepodległość, przyczynić się do powstania państwa ukraińskiego. Dziś można powiedzieć, że realizował program antykolonialny. Był świadomy znaczenia tożsamości i odrębności ukraińskiej w procesie konsolidacji całego narodu, niezależnych od kwestii terytorialnych. Uważał, że Ukraińcy muszą nauczyć się być po prostu Ukraińcami, nie zaś mieszkańcami Galicji, Ukraińcami z Bukowiny czy Ukrainy Naddnieprzańskiej, ale właśnie Ukraińcami, którzy nie baczą na dzielące ich granice ${ }^{24}$.

W duchu idei łączenia Ukraińców ponad oficjalnymi granicami pozostaje znajomość Franki z rodziną Kosaczów-Drahomanowów. Matka Łesi Ukrainki - Ołena Pcziłka, pisarka i aktywna propagatorka działań na rzecz kultury ukraińskiej, świadomie i konsekwentnie podtrzymywała znajomość z Franką, który był bliskim znajomym jej brata Mychajła Drahomanowa wybitnego uczonego, historyka, członka kijowskiej Hromady, wreszcie emigranta, któremu nie było dane powrócić do ojczyzny. Iwan Franko był ważną postacią nie tylko w życiu Kosaczów-Drahomanowów, których był częstym gościem ${ }^{25}$, ale przede wszystkim ważną osobistością dla rozwoju literackie-

$21 \quad$ Ibidem, s. 287.

22 Szerzej na ten temat m.in. [w:] M. Riabczuk, Gogol i wojna tożsamości, przeł. K. Kotyńska, [w:] Idem, Ukraina. Syndrom postkolonialny, Wrocław - Wojnowice 2015, s. 102-119.

23 I. Франко, Зібрання творів: У 50-ти томах, t. 3, s. 581.

24 I. Франко, Зібрання творів: У 50-ти томах, t. 45, s. 405.

25 Warto dodać, że Ołena Pcziłka zaaranżowała małżeństwo Franki z Olgą Chorużynską - córką członka kijowskiej Hromady. Małżeństwo tych dwojga: Franki - Galicjanina i Chorużynskiej - reprezentantki Ukrainy Naddnieprzańskiej było postrzegane przez ówczesne 
go i kulturalnego Ukrainy Naddnieprzańskiej - to między innymi za jego pośrednictwem we Lwowie drukowano utwory ukraińskie w ojczystym języku, bo nie miały one prawa pojawić się w zaborze carskim. Również Łesia Ukrainka - wybitna córka swojej matki - współpracowała z Franką. Pisarka znała go od wczesnego dzieciństwa. Dzięki wsparciu i pomocy Franki został opublikowany jej pierwszy wiersz Nadija (poetka miała wówczas 9 lat). Można powiedzieć, że Franko był ojcem chrzestnym debiutu literackiego Łesi i, jak się później okazało, częstym krytykiem jej dojrzałej twórczości. Główną rolę w ukształtowaniu fenomenu, jakim była dla literatury i kultury ukraińskiej Łarysa Kosacz (Łesia Ukrainka), odegrała jej matka - Ołena Pcziłka, która ułożyła dla córki specjalny humanistyczny program nauczania domowego i dbała o jej wychowanie w duchu narodowym, a nawet wymyśliła pseudonim literacki. Jednakże to właśnie Franko bezpośrednio przyczynił się do debiutu Łesi Ukrainki, a zatem jej faktycznego zaistnienia w przestrzeni publicznej. Także później znaczna część twórczości poetki, z nielicznymi wyjątkami, została opublikowana przy udziale i redakcyjnym zaangażowaniu Franki. Rzecz jasna, edycjom poezji Łesi Ukrainki towarzyszyły obszerne recenzje tego pisarza, co stanowiło dla autorki nieocenioną wartość. Artykuły Franki były idealnym, chociaż pojedynczym głosem profesjonalnego, bo gruntownie filologicznie i humanistyczne przygotowanego krytyka literackiego.

Chociaż twórców dzieliła spora różnica wieku (Łesia Ukrainka była młodsza od Franki o 15 lat), byli oni przyjaciółmi, czasem ostro ze sobą polemizującymi, jak to miało miejsce po publikacji artykułu Franki 3 кінщем сезону w czasopiśmie „Життє і Слово” (księga IV, 1896), w którym pisarz skrytykował naddnieprzańskich Ukraińców za to, że w pierwszej kolejności utożsamiają się z ideami socjalizmu, a dopiero potem z Ukrainą. Zachęcał ich też do systematycznej pracy dla ojczystego kraju, nawoływał do rozbudzania świadomości narodowej wśród najniższych warstw społeczeństwa ukraińskiego; przekonywał, by nie ulegać wpływom ponadnarodowych idei socjalistów rosyjskich i skierować „свої великі сили на працю для того ідеалу серед рідного народу [...] задля справи вільної, автономної України"»². Łesia Ukrainka, będąc wówczas pod wpływem swojego wuja Mychajła Drahomanowa, zbliżyła się do radykalnych ukraińskich kół socjalistycznych i w odpowiedzi na artykuł Franki w czasopiśmie „Життє і Слово” (księga II, 1897) opublikowała bulwersującą odpowiedź pod tytułem Не так miї вороги, як добрії люди, w którym obwiniła Frankę o to, że nawołuje do dawno przebrzmiałego narodnictwa. Ostro skrytykowała również styl artykułu Fran-

środowisko kijowskie jako wyraz idei łączności duchowej i politycznej Ukrainy Wschodniej i Zachodniej.

26 Ibidem, s. 229. 
ki. Poeta i zarazem redaktor czasopisma nie tylko opublikował artykuł, ale zamieścił jednocześnie swój komentarz pod tytułem Як не по конях, по по оглоблях (później poruszony wątek tematyczny znalazł się w artykule Мiж своїми. Епізод із взаємин між галичанами і українцями 1897 року27). Chociaż Łesia podkreślała: „Я завжди вміла відрізняти публіцистику від приватних справ" 28 , polemika i reakcja Franki do głębi poruszyła i rozgniewała poetkę, która nie skrywała urazy. Kiedy Fanko pod presją złej sytuacji finansowej był zmuszony do zamknięcia czasopisma „Житте і Слово”, а został współredaktorem nowo otwartego „Літературно-Наукового Вісника”, zaprosił młodszą pisarkę do współpracy. W liście do matki poetka infantylnie pisała: „Читаючи лист, я не могла не подумати: «прийшла коза до воза». Тим часом я відповіла йому в дуже гречному тоні, без жадних натяків на «козу», і послала два вірші". Wydaje się, że „nie taka znów koza”, to był raczej gest wielkoduszności ze strony Franki, w końcu pisarka i tak nie miała gdzie publikować swoich utworów i artykułów; przypomnijmy, że na terenach ukraińskich wchodzących w skład Imperium Rosyjskiego nie wolno było publikować w języku ukraińskim. Pisarka kończy kwestię konfliktu słusznym uogólnieniem: „Властиво, я рада такому закінченню нашого «конфлікту», бо толку з нього не було жадного, а Франка яко писателя і діяча я ніколи не переставала поважати"29.

Łesia Ukrainka zawsze odnosiła się do Franki z szacunkiem, ale nie schlebiała mu, traktując go jak równego sobie. Wynikało to z jej życiowej, moralno-psychologicznej postawy opartej na takich zasadach, jak szacunek dla siebie samej, poczucie własnej wartości i godności, sprawiedliwość, równoprawność, sprzeciw wobec wszelkiej dominacji czy ucisku, zarówno w życiu osobistym, jak i pod względem światopoglądowym, w dziedzinie twórczości czy w odniesieniu do praw narodu ukraińskiego. Takie były jej główne zasady, na których budowała indywidualną oraz zbiorową tożsamość narodową; nigdy od nich nie odeszła, choć, jak każdy człowiek, zmieniała się wraz z upływem czasu.

Łarysa Kosacz wychowywała się w jednej z niewielu inteligenckich, świadomych pod względem narodowym rodzin ukraińskich, jakie żyły w tamtym czasie. Zostawszy przez przypadek, jak można powiedzieć, Łesią Ukrainką we wczesnej młodości, przyjęła jako swój nie tylko los pisarza ukraińskiego, ale i los Ukrainy. Nigdy później nie zmieniła tego, aż nadto wymownego, imienia literackiego. Sam pseudonim niósł w sobie informację o jej oporze wobec kolonialnej polityki rosyjskiej i już to pseudo-imię było manifestacją ukraińskiej tożsamości. Władze rosyjskie propagowały wówczas nazwę

27 І. Франко, Додаткові томи до зібрання творів у 50-и томах, t. 54, Київ 2010, s. 800831.

28 Л. Українка, Зібрання творів у 12-ти томах, t. 10, Київ 1978, s. 413.

29 Ibidem, s. 413-414. 
Małorosja na określenie ziem ukraińskich wchodzących w skład imperium, taka nazwa była przez nie stosowana oficjalnie. Ukraińcy byli konsekwentnie nazywani Małorusami, w których władze rosyjskie chciały mieć wiernych, podporządkowanych sobie obywateli imperialnych peryferii (kolonii), mających szansę wspinania się po szczeblach kariery w różnych obszarach życia społecznego, przede wszystkim w Moskwie czy Petersburgu. Jednakże ceną, jaką musieli płacić poszukujący dobrobytu, zaszczytów i sławy, było wynarodowienie oraz przyjęcie rosyjskiej optyki.

Wybrany przez matkę poetki pseudonim nie tylko podkreślał jej narodową tożsamość, ale także przynależność do tej grupy inteligencji, która w opozycji do oficjalnego nazewnictwa używała nazwy „Ukraina” oraz „Ukraińcy”, a pamiętać należy, że określeniami tymi posługiwała się w tamtym czasie przede wszystkim inteligencja rosyjskiej Ukrainy, głównie Kijowa. Podkreślające fakt przynależności do narodu ukraińskiego imię niosło ze sobą ważny komunikat, zwłaszcza dla środowiska galicyjskiego, lwowskiego, w którym poetka debiutowała. Dzięki niemu Rusini z Galicji wiedzieli, że mają do czynienia z autorką pochodzącą z Ukrainy Naddnieprzańskiej, która w sposób demonstracyjny informuje czytelników o swoim stosunku do imperialnej polityki rosyjskiej, odrzucając oficjalną nazwę narodu małorosyjskiego, a co gorsza chachłackiego $(!)^{30}$.

Nie ma informacji, czy poetka dobrze się czuła ze swoim pseudonimem i czy nie chciała go zmienić. Faktem jest, że przyjęte imię w pewnym sensie zamknęło jej drogę do szerszego grona odbiorców reprezentujących inne kultury, gdyż ukazywało pisarkę zawsze przez pryzmat jej narodowości i postawy patriotycznej, a co za tym idzie, naznaczało piętnem lokalności, prowincjonalności, z którymi, o ironio, starała się walczyć w swej działalności oraz twórczości. Interpretując postawę poetki, należy podkreślić, że jednocześnie należała ona do grupy Ukraińców, którzy przyjmowali za swoje to wszystko, co wiązało się z ukraińską tożsamością, poczuwali się do wspólnoty ze wszystkimi jej nosicielami, nawet tymi nieuświadomionymi, czyli z prostym ludem. Pseudonim poetki doskonale wpisywał się zatem w jej życiową i twórczą postawę, a jednocześnie nakładał na nią gorset obowiązku pozostawania w literaturze przede wszystkim Ukrainką, a dopiero później poetką, kobietą, itp. Determinował jej pierwszą tożsamość jako narodową, spychając pozostałe na margines.

\footnotetext{
30 Ciekawe, że Gogol, o którym już była mowa, zastanawiając się nad swoim wewnętrznym rozdwojeniem, pisał, że sam nie wie, jaką ma duszę - chachłacką czy rosyjską, poddając się imperialnej retoryce, bo określenie chachłacki ma pejoratywny wydźwięk. Jednak warto zauważyć, poniekąd usprawiedliwiając pisarza, że czas życia i twórczości Gogola przypadł na okres sprzed pojawienia się tzw. idei ukraińskości, którą wiąże się z Tarasem Szewczenką oraz Bractwem Cyryla i Metodego. Można powiedzieć, że Gogol wszedł do literatury za wcześnie, kiedy okoliczności polityczne niemalże determinowały jego pisarską drogę, jednocześnie były przyczyną wewnętrznego rozdarcia, konfliktu z samym sobą.
} 
Czas życia Łesi Ukrainki przypada na ten okres historii narodu ukraińskiego, na którym wyraźnie odcisnęła swoje piętno rosyjska polityka kolonizatorska, która w jakiejś mierze wynikała z lęku władzy przed możliwym ukraińskim separatyzmem, jak również z obaw płynących z wiedzy o słabości rosyjskiej idei imperialnej, zbudowanej, jak by nie było, w dużej mierze kosztem Ukrainy i jej historii. Pisarze ukraińscy należeli do tej kategorii społeczeństwa, którym bacznie się przyglądano, ponieważ nie można było nakazami i zakazami skrępować swobody ich myśli; często to właśnie oni - jak to ujmuje Stefania Andrusiw - w nieistniejącym języku starali się prezentować i reprezentować tak językową, jak i kulturową odrębność Ukrainy, tworząc tym samym, świadomie bądź też nie, dyskurs antykolonialny ${ }^{31}$. Taką właśnie narrację poprzez swoją twórczość, ale także i działalność, prowadziła Łesia Ukrainka. Twórczość pisarki była „голосом однієї російської ув’язненої”, ale jednocześnie był to głos całej podbitej, skolonizowanej Ukrainy.

Należy podkreślić, że wspomniany dyskurs narodowo-wyzwoleńczy obecny jest w większym czy mniejszym natężeniu w całej spuściźnie literackiej poetki, począwszy od pierwszego utworu, a na ostatnim skończywszy. Wymownym przejawem antykolonialnej postawy pisarki była dążność do unowocześnienia literatury ukraińskiej, pragnienie wydobycia jej z przestrzeni zaściankowości i śmieszności, którą dotychczas zajmowała, przeniesienia w obszar literatury powszechnej, zwłaszcza europejskiej. W tym celu poetka wprowadzała do literatury ukraińskiej wielkie obrazy kultury europejskiej, które, jak w przypadku Don Juana, po raz pierwszy przemówiły do czytelników bezpośrednio w języku ukraińskim, a nie w języku przekładu:

Боже, прости мене і помилуй! Я написала „Дон-Жуана”! Отого-таки самого, „всесвітнього і світового”, не давши йому навіть ніякого псевдоніма. [...] Так чи інакше, але от уже і в нашій літературі $\epsilon$ „Дон Жуан” власний, неперекладений, оригінальний тим, що його написала жінка (се, здається, вперше трапилось сій темі $)^{32}$.

Listy ukazujące tło powstania oraz pomagające zinterpretować Don Jua$n a$ Łesi Ukrainki dostarczają jednocześnie wielu cennych informacji dotyczących postawy poetki. Twórczyni ujawnia świadomość ciężaru odpowiedzialności, jaką wzięła na siebie, sięgając po postać osadzoną w ponadnarodowej tradycji literackiej. Czuje się odpowiedzialna tak wobec literatury ukraińskiej,

\footnotetext{
31 С. Андрусів, Конструювання ідентичностей у життєтворчості Лесі Украӥнки. Постколоніальна перспектива, „Roczniki Humanistyczne” 2012, z. 7, seria: Stowianoznawstwo, t. LX, s. 26.

32 List do A. Krymskiego (24.05.1912), [w:] Л. Українка, Зібрання творів у 12-ти томах, t. 12, Київ 1979, s. 396.
} 
jak i powszechnej, z której zaczerpnęła ustaloną już figurę oraz związane z nią znaczenia.

W innym liście poetka konfrontuje swoją postawę z poglądami Piotra Struwego i jego otoczenia, które, co ciekawe, określa mianem „starszych braci” (!), posługując się kodami narracji imperialnej:

Як Ви зараз же побачите по списку діячів, єсть се не більше не менше як українська версія світової теми про Дон Жуана. „До чего дерзность хохлацкая доходит”, - скаже Струве і вся чесна компанія наших „старших братів”з3.

Pisarka wkracza w polemikę z rosyjskim publicystą - agresywnym ukrainofobem, niejako kontynuatorem polityki marginalizowania ruchu ukraińskiego, zapoczątkowanej przez Wisariona Bielinskiego, zgodnie z którą „,chachłaccy pisarze marnują swoje talenciki na tworzenie śmiesznej i nikomu nie potrzebnej literatury ukraińskiej" ${ }^{34}$. Z góry zakładano, że taka literatura nie może zaoferować nic wartościowego, dlatego powinna koncentrować się na ludowości, folklorze, a nie podejmować poważnych narracji, rzekomo zarezerwowanych dla wielkich, jak rosyjska, literatur. Łesia Ukrainka uważała zgoła inaczej i w tym też celu unowocześniała literaturę ukraińską nie tylko $\mathrm{w}$ warstwie obrazów, narracji, ale też $\mathrm{w}$ warstwie artystycznej i w zakresie gatunków literackich. Ze szczególnym upodobaniem zwracała się ku formom dramatycznym, nawiązując zarówno do tradycji dramatu antycznego, jak i zwracając się ku współczesności nowego dramatu europejskiego. Pisarka pragnęła, by ukraińska literatura wreszcie znalazła się w strefie oddziaływania kultury europejskiej, aby stała się uczestnikiem „cyrkulacji myśli i wymiany idei”, żeby nie była jedynie biernym obserwatorem, a taką właśnie rolę konsekwentnie wskazywała jej imperialna polityka rosyjska.

Cel, jaki obrała sobie Łesia Ukrainka już we wczesnej młodości, realizowała również, tłumacząc na język ukraiński dzieła z obcych literatur. Poetka znała kilka języków, czytała zatem literaturę światową oraz prace literaturoznawcze w oryginale. Uzyskaną wiedzę referowała następnie rodakom, dodając własny komentarz; poszerzała tym samym ich horyzont kulturowy oraz światopoglądowy. Wszystkie te działania, których ze zrozumiałych względów wówczas nie określano mianem antykolonialnych, stanowią przykład takiej właśnie postawy i aktywności, gdyż celem ich było z jednej strony zlikwidowanie poczucia niedowartościowania, zaściankowości, prowincjonalności, których często doznawali Ukraińcy, a z drugiej potwierdzenie swojego odrębnego, niezależnego prawa głosu, który temu narodowi odbierano, chociażby poprzez forsowną rusyfikację.

33 List do L. Staryckiej-Czerniachiwskiej (czerwiec 1912), [w:] Л. Українка, Зібрання творів..., t. 12, s. 399-400.

34 В. Белинский, Полное собрание сочинений, t. 5, Москва 1954, s. 330. 
Sprzeciw wobec niewoli swojego narodu wyrażała Łesia, konsekwentnie posługując się językiem ukraińskim, poprzez który podkreślała inność i odrębność swoją i swojego narodu. Ostentacyjnie, wydaje się, że nawet trochę na wyrost, pisarka podkreślała, iż chociaż jest poddaną rosyjską, to język rosyjski zna o wiele gorzej niż francuski. Był to świadomy antykolonialny gest sprzeciwu wobec imperialnej propagandy. Ukraińska dusza poetki nigdy nie zaznała rozdwojenia, jak to miało miejsce wcześniej w przypadku Gogola. Taka postawa pisarki była wynikiem nie tylko wychowania, jakie otrzymała; jej poczucie tożsamości narodowej było też kontynuacją tradycji ukrainofilskiej - realizacją jawnej lub ukrytej postawy „mazepiństwa”, czyli ukraińskich dążeń niepodległościowych.

Jądro narracji tożsamościowej Łesi Ukrainki stanowiła jej obszerna twórczość, a w omawianym kontekście szczególne miejsce zajmuje utwór Bojarynia, w którym autorka używa nazwy Ukraina i przedstawia początki procesu kolonizowania swojego kraju. Otwarcie, nie pod osłoną poetyckich obrazów, mówi o Ukrainie, jej tragicznym położeniu, ucisku i niewoli, jak również o jej odmienności, o tym, co odróżnia ją od Rosji. Na marginesie warto dodać, że był to jedyny utwór w całej spuściźnie autorki wykluczony przez radziecką cenzurę.

Reasumując, warto podkreślić, że zarówno Iwan Franko, jak i Łesia Ukrainka byli nie tylko wybitnymi twórcami literatury ukraińskiej, autorami utworów o wysokiej wartości artystycznej, ale w równej mierze Ukraińcami świadomie i konsekwentnie propagującymi ideę ukraińskiej wolności oraz narodowej, kulturowej, wreszcie historycznej odrębności. Ukraińska tożsamość narodowa oraz zadanie jej kształtowania stanowily dla obojga twórców kwestię priorytetową. Jak się jednak okazuje, cele, które sobie wytyczyli, okazały się możliwe do osiągnięcia tylko w trudnym, złożonym i długotrwałym procesie, niezakończonym do dnia dzisiejszego.

\section{BIBLIOGRAFIA}

Andrusìv Stefanìâ. 2012. Konstruûvannâ identičnostej u žittêtvorčostì Lesì Ukraïnki. Postkolonial'na perspektiva. „Roczniki Humanistyczne” z. 7: Słowianoznawstwo, t. LX: 23-37 [Андрусів Стефанія. 2012. Конструювання ідентичностей у життєтворчості Лесі Украӥнки. Постколоніальна перспектива. „Roczniki Humanistyczne" z. 7: Słowianoznawstwo, t. LX: 23-37].

Belinskij Vissarion. 1954. Polnoe sobranie sočinenij. T. 5. Moskva: Izdatel'stvo Akademii Nauk SSSR: 328-401[Белинский Виссарион. 1954. Полное собрание сочинений. T. 5. Москва: Издательство Академии Наук СССР: 328-401].

Fannon Frantz. 1985. Wyklęty lud ziemi. Tłum. Tygielska H. Warszawa: Państwowy Instytut Wydawniczy.

Franko İvan. 1976. Zibrannâ tvorìv u 50-i tomah. T. 3. Kiïv: Naukova dumka [Франко Іван. 1976. Зібрання творів у 50-и томах. Т. 3. Київ: Наукова думка]. 
Franko İvan. 1980. Zỉbrannâ tvorìv u 50-i tomah. T. 27. Kï̈v: Naukova dumka [Франко Іван. 1980. Зібрання творів у 50-и томах. Т. 27. Київ: Наукова думка].

Franko İvan. 1986. Zibrannâ tvorìv u 50-i tomah. T. 45. Kiïv: Naukova dumka [Франко Іван. 1986. Зібрання творів у 50-и томах. Т. 45. Київ: Наукова думка].

Franko İvan. 2001. Ukraina irredenta. W: Franko İ. Mozaïka: İz tvorìv, ŝo ne uvijšli do Zibrannâ tvorìv u 50 tomah. Uporâd. Franko Z., Vasilenko M. L'vìv: Kamenâr [Франко Іван. 2001. Ukraina irredenta. W: Франко I. Мозаїка: Із творів, щзо не увійшли до Зібрання творів у 50 томах. Упоряд. Франко 3., Василенко М. Львів: Каменяр].

Franko İvan. 2010. Dodatkovi tomi do zibrannâ tvorìv u 50-i tomah. T. 54. Kiïv: Naukova dumka [Франко Іван. 2010. Додаткові томи до зібрання творів у 50-и томах. Т. 54. Київ: Наукова думка].

Gricak Âroslav. 1996. Narisi istorï Ukraïni: formuvannâ modernoï ukraïns'koï nacï XIX-XX st. Kï̀v: Geneza [Грицак Ярослав. 1996. Нариси історії України: формування модерної української нації XIX-XX ст. Київ: Генеза].

Gricak Âroslav. 2006. Prorok u svoï Vitčizni: Franko ta jogo spil'nota (1856-1886). Kï̀v: Kritika [Грицак Ярослав. 2006. Пророк у своїй Вітчизні: Франко та його спільнота (1856-1886). Київ: Критика].

Reid Anna. 2016. Pogranicze. Podróż przez historię Ukrainy 988-2015. Tłum. Tyszka W. Warszawa: Wydawnictwo Literackie.

Riabczuk Mykoła. 2015. Gogol i wojna tożsamości. W: Riabczuk M. Ukraina. Syndrom postkolonialny. Tłum. Kotyńska. K. Wrocław - Wojnowice: KEW: 102-119.

Riabczuk Mykoła. 2015. Kolonializm inaczej. O przydatności metodologii postkolonialnej do badań nad Europa postkomunistyczna. W: Riabczuk M. Ukraina. Syndrom postkolonialny. Tłum. Kotyńska K. Wrocław - Wojnowice: KEW: 20-36.

Said Edward. 2005. Orientalizm. Tłum. Wyrwas-Wiśniewska M. Poznań: Zysk i S-ka.

Skórczewski Dariusz. 2013. Teoria - Literatura - Dyskurs. Pejzaż postkolonialny. Lublin: Wydawnictwo KUL.

Ukraïnka Lesâ. 1978. Zibrannâ tvorìv u 12-ti tomah. T. 10. Kiïv: Naukova dumka [Українка Леся. 1978. Зібрання творів у 12-ти томах. Т. 10. Київ: Наукова думка].

Ukraïnka Lesâ. 1979. Zibrannâ tvorìv u 12-ti tomah. T. 12. Kï̈v: Naukova dumka [Українка Леся. 1979. Зібрання творів у 12-ти томах. Т. 12. Київ: Наукова думка].

Vinničenko Volodimir. 1990. Sodennik № 9. Kiїv: 88-122 [Винниченко Володимир. 1990. Щоденник № 9. Київ: 88-122].

\title{
UKRAINIAN NARRATIVES ABOUT NATIONAL IDENTITY: THE EXAMPLE OF IVAN FRANKO AND LESYA UKRAINKA
}

\begin{abstract}
The author of the present paper analyzes the selected examples of Ukrainian identity depicted in literary works of the two Ukrainian great writers who lived in two politically separate parts of Ukraine. Both Ivan Franko and Lesya Ukrainka pointed out that only due to strengthening their national identity Ukrainians can preserve their national distinctiveness.
\end{abstract}

Key words: Ivan Franko, Lesya Ukrainka, Ukrainian national identity, Ukrainian literature, Ukrainian writers. 


\section{УКРАЇНСЬКІ НАРАЦІЇ ПРО ІДЕНТИЧНІСТЬ. ПРИКЛАД ІВАНА ФРАНКА ТА ЛЕСІ УКРАЇНКИ}

Анотація. Авторка статті аналізує вибрані приклади творчості Івана Франка та Лесі Українки, де піднімаються питання української ідентичності, необхідність ії розбудови та зміцнення, адже тільки тоді Україна та українці спроможні проголосити свою окремість, політичну незалежність. Письменники, які представляють розділені політичними кордонами українські землі, використовують антиколоніальну нарацію у своїй творчості.

Ключові слова: Іван Франко, Леся Українка, українська ідентичність, національна ідентичність, українська література, українські письменники. 